\title{
Bio-synthetic natural gas as fuel in steel industry reheating furnaces - a case study of economic performance and effects on global $\mathrm{CO}_{2}$ emissions
}

\author{
Maria T Johansson ${ }^{1,2}$ \\ ${ }^{1}$ Department of Management and Engineering, Division of Energy Systems, Linköping University, SE-581 83 \\ Linköping, Sweden \\ 2.Department of Technology and Built Environment, Division of Energy and Mechanical Engineering, \\ University of Gävle, SE-801 76 Gävle, Sweden
}

Corresponding author. E-mail address: maria.johansson@liu.se Fax: +4613281788

\begin{abstract}
Climate change is of great concern for society today. Manufacturing industries and construction account for approximately $20 \%$ of global $\mathrm{CO}_{2}$ emissions and, consequently, it is important that this sector investigate options to reduce its $\mathrm{CO}_{2}$ emissions. One option could be to substitute fossil fuels with renewable alternatives. This paper describes a case study in which four future energy market scenarios predicting 2030 were used to analyse whether it would be profitable for a steel plant to produce bio-synthetic natural gas (bio-SNG) in a biomass gasifier and to substitute liquefied petroleum gas (LPG) with bio-SNG as fuel in reheating furnaces. The effects on global $\mathrm{CO}_{2}$ emissions were analysed from a perspective in which biomass is considered a limited resource. The results from the analysis show that investment in a biomass gasifier and fuel conversion would not be profitable in any of the scenarios. Depending on the scenario, the production cost for bio-SNG ranged between 22-36 EUR/GJ. Fuel substitution would reduce global $\mathrm{CO}_{2}$ emission if the marginal biomass user is a producer of transportation fuel. However, if the marginal user of biomass is a coal power plant with wood co-firing, the result would be increased global $\mathrm{CO}_{2}$ emissions.
\end{abstract}

Keywords: Biomass gasification, Steel industry, Case study, Fuel substitution, Bio-synthetic natural gas (bio$\mathrm{SNG}), \mathrm{CO}_{2}$ emissions

\section{List of abbreviations}

$\begin{array}{ll}\text { AOD } & \text { Argon-oxygen-decarburization } \\ \text { ASU } & \text { Air separation unit } \\ \text { BF } & \text { Blast furnace } \\ \text { Bio-HOB } & \text { Bio heat only boiler } \\ \text { Bio-SNG } & \text { Bio-synthetic natural gas } \\ \text { BOF } & \text { Basic oxygen furnace } \\ \text { DH } & \text { District heating } \\ \text { CHP } & \text { Combined heat and power } \\ \text { CRF } & \text { Capital recovery factor } \\ \text { ENPAC tool } & \text { Energy Price and Carbon Balance Scenarios tool } \\ \text { FT } & \text { Fischer Tropsch } \\ \text { LPG } & \text { Liquefied petroleum gas } \\ \text { NAP } & \text { Net annual profit }\end{array}$




$\begin{array}{ll}\text { NGCC } & \text { Natural gas combined cycle } \\ \text { PEF } & \text { Primary energy factor } \\ \text { TIC } & \text { Total investment cost }\end{array}$

\section{Introduction}

Climate change caused by anthropogenic greenhouse gas emissions is of great concern for society. In 2011, global $\mathrm{CO}_{2}$ emission from fossil fuel combustion reached 31.6 Gtonnes [1]. Manufacturing industries and construction account for approximately $20 \%$ of global $\mathrm{CO}_{2}$ emissions [2]. Therefore this sector has the potential to contribute to significantly reducing $\mathrm{CO}_{2}$ emissions through energy-efficiency measures, energy recovery and conversion to renewable energy sources. Policies and legislation have put increased pressure on industry to improve its energy efficiency and reduce its $\mathrm{CO}_{2}$ emissions [3].

The iron and steel industry accounts for $14 \%$ of the world's industrial energy use [4] and relies to a great extent on fossil fuels, for example, coke is used in blast furnaces, and natural gas is used in reheating furnaces and basic oxygen furnaces while oil and liquefied petroleum gas (LPG) are used as fuel in reheating furnaces. Ultra Low $\mathrm{CO}_{2}$ Steelmaking (ULCOS) is a European research programme, which aims to reduce $\mathrm{CO}_{2}$ emissions from steelmaking by $50 \%$, compared to best practices of 2004 [5]. The programme investigates new steelmaking technologies and analyses options for using biofuel in the steel industry. Options for substitution of fossil fuels with renewable alternatives in the iron and steel industry include replacement of fossil coal and coke with charcoal [6-9] and substitution of fossil fuels in reheating furnaces with synthetic natural gas (SNG) produced through gasification of biomass [10]. For steel companies currently using natural gas as a fuel, bio-SNG is a convenient substitute; because the composition of these fuels is virtually the same no adjustments has to be made in the furnaces.

Integration of biomass gasification within different industries has been studied. Johansson et at. [11] analysed integration of three concepts for biomass gasification in an oil refinery and the results showed potential for global $\mathrm{CO}_{2}$ emission mitigation if biomass was considered an unlimited resource. However, if biomass was considered a limited resource and the marginal user of biomass was a coal power plant with co-firing of biomass, global $\mathrm{CO}_{2}$ emissions would increase for all the biomass gasification concepts. The reason for this is that when the biomass is purchased by the gasification plant the coal power plant has to burn coal instead of biomass. Wetterlund et al. [12] and Isaksson et al. [13] examined the integration of biomass gasification with pulp and paper production. In the former study the results showed that biomass gasification could be profitable for a thermochemical pulp mill [12]. Profitability was highly dependent on future energy market parameters, particularly policy support. The study also concluded that if the syngas from the biomass gasifier was used for combined heat and power generation, there was a potential for reduced global $\mathrm{CO}_{2}$ emissions. However, the latter study showed that integration of a biomass gasifier with a thermal mechanical pulp mill results in larger global $\mathrm{CO}_{2}$ emissions than if the two facilities were operating independently [13]. Buergler et al. [14] studied integration of biomass gasification with sponge iron production (DRI production); bio-syngas produced was used as reducing agent in the process in which iron ore is converted into metallic iron.

In order to estimate a potential for reducing $\mathrm{CO}_{2}$ emissions from the iron and steel industry, numerous options to substitute fossil fuels should be analysed. It is also of interest to investigate more prospects to integrate biomass gasification with industry to increase the possibility of market penetration of the technology. Therefore, this paper analyses the economic aspects and $\mathrm{CO}_{2}$ emissions reduction potential of substituting LPG with bio-SNG as fuel in reheating furnaces at a scrap-based steel plant. 


\section{Aim and delimitations}

The aim of this paper is to investigate profitability for a case study steel plant to produce bio-SNG in a biomass gasifier and to substitute LPG with bio-SNG as fuel in reheating furnaces. Another aim is to analyse how the fuel substitution would affect global $\mathrm{CO}_{2}$ emissions. Four future energy market scenarios were used to analyse net annual profit (NAP) for investment in a biomass gasifier and to analyse effects on global $\mathrm{CO}_{2}$ emissions. Externality costs and co-benefits such as health benefits and other environmental benefits for substituting LPG with bio-SNG are not included in the analysis. The costs for transportation of LPG and wood pellets and for required modifications in the steel plant, (e.g., investment in new burners in the reheating furnaces, new gas distribution system and exhaust gas cleaning system) are not included in the economic analysis. Because the results of the analysis will provide information on the investment opportunity for such modifications, the results are of a general character.

\section{Biomass gasification and methanation}

Gasification of biomass is thermochemical conversion of biomass into a product gas called syngas or synthesis gas. Syngas is mainly comprised of carbon monoxide $(\mathrm{CO})$ and hydrogen $\left(\mathrm{H}_{2}\right)$ with smaller amounts of methane $\left(\mathrm{CH}_{4}\right)$, carbon dioxide $\left(\mathrm{CO}_{2}\right)$ and steam. Syngas can be converted into a number of products such as Fischer Tropsch (FT) diesel, bio-SNG, methanol, ethanol, dimethyl ether (DME) and ammonia. Often the gasification step is followed by a shift reaction (water-gas shift reaction) in which the $\mathrm{H}_{2}$-to-CO ratio is adjusted to match the downstream application. [15]

Thermochemical conversion of biomass into bio-SNG principally includes the following steps: 1) pretreatment of biomass; 2) gasification; 3) shift reaction; 4) gas-cleaning; 5) methanation; and 6) up-grading.

The pre-treatment step can include the removal of foreign materials (e.g., rocks and metal), drying to reduce the moisture content and reduction in the size of particles (e.g., chipping, grinding and pulverization) [15].

In the gasification process, air, steam and/or oxygen $\left(\mathrm{O}_{2}\right)$ are used as gasifying agents and syngas is produced when the agent reacts with the solid carbon and hydrocarbons in the biomass. The lower heating value (LHV) of the produced syngas depends on the gasifying agent; when air, steam and oxygen are gasifying agent the results are a syngas with an LHV of 4-7, 10-18 and $12-28 \mathrm{MJ} / \mathrm{Nm}^{3}$, respectively. There are three main gasification technologies: fixed-bed/moving-bed reactor, fluidized bed reactor, and entrained-flow reactor [15]. Fixed-bed gasifiers are normally simpler and less expensive and produce a syngas with a lower heating value. Fluidized-bed gasifiers and entrained-flow gasifiers are more complex and more expensive and produce a syngas with a higher heating value. [16]

The syngas contains impurities, including particulates, tars, sulphur compounds, nitrogen compounds and alkali compounds that have to be removed. The choice of gas cleaning systems depends on how the syngas will be used. If particulates need to be removed from the syngas, a simple gas cleaning technique can be done using a gas cyclone. If the syngas is to be used to synthesis of chemicals or transportation fuel, a more thorough cleaning has to be performed (e.g., high temperature filter or wet scrubber). [16]

If the syngas is used for the production of SNG, a methanation step is added to the gasification system; in this step, $\mathrm{H}_{2}$ and carbon react and form $\mathrm{CH}_{4}$. High pressure has a positive influence on the reaction speed [15]. After the methanation, the bio-SNG is upgraded and $\mathrm{CO}_{2}$ and water are removed. The methanation reaction is highly exothermic and offers options for heat recovery.

Gasification of biomass is not yet a commercialised technology, but several biomass gasification projects are ongoing. Göteborg Energi's GoBiGas initiative has launched the first phase of constructing a commercial gasification plant in Gothenburg, Sweden [17]. This phase, which is due to be completed in 2013, is 
construction of a demonstration plant with a bio-SNG production capacity of $20 \mathrm{MW}_{\text {bio-SNG. }}$ In the second phase, a commercial plant with a bio-SNG production of 80-100 $\mathrm{MW}_{\text {bio-SNG }}$ will be built. This is planned to be in operation by 2016.

Gasification plants are designed for continuous operation and expected to operate in the 85 to $95 \%$ availability range [16].

\section{Iron and steel industry}

There are three main ways to produce steel: 1 ) iron ore-based steel production in a blast furnace - basic oxygen furnace (BF-BOF); 2) iron ore-based steel production through direct reduction; and 3) scrap-based steel production.

In the BF-BOF route, iron ore pellets and coke are charged into the BF. At temperatures between 1500 and $2000^{\circ} \mathrm{C}$, the iron ore is melted and the iron oxides in the ore are reduced into metallic iron (hot metal) when oxygen in the iron oxides combines with carbon in the coke. The hot metal is then charged into a BOF vessel. Pure oxygen is blown into the BOF and the carbon content of the hot metal is reduced when the carbon is oxidized. During this reaction, large amounts of heat are released and steel scrap is added which can be melted without using additional energy. The hot steel produced undergoes further refining in secondary refining processes (e.g., addition of different alloys). Finally, the steel is cast and sent to steel works for processing into products such as wire, sheets and tubes. [18]

In the direct reduction process, the iron oxides in iron ore are reduced into metallic iron in a solid-state reduction at lower temperatures, $900-1000{ }^{\circ} \mathrm{C}$. The reducing agent is often natural gas. The resulting iron is then melted in an electric arc furnace or an electric induction furnace and the hot metal is further refined in the same way as in the BF-BOF process. [18]

In scrap-based production, steel scrap is melted in an electric arc furnace and the composition of the melted steel is then adjusted in an argon-oxygen-decarburization (AOD) converter. Alloys can be added to the steel while it is in the AOD or in a ladle after the AOD process. Finally, the steel is cast and sent to steel works. [19]

In the steel works, steel is processed, e.g. through forging, rolling, drawing and extrusion. These processes generally involve heating the steel in reheating furnaces, which can be induction or fuel-fired. The fuel-fired furnaces often use LPG, oil or natural gas as fuel. However, if the steel works is integrated with an iron works using a blast furnace process, reheating furnaces can be fired with energy-rich gases from coke ovens, BF and BOF.

In Sweden, steel companies are highly specialized and several Swedish steel producers are world leaders in the production of advanced steel. 'Advanced steel products' imply a high degree of processing, which in many cases involves repeated heating and cooling operations. Moreover, the majority of Swedish scrapbased steel plants use LPG as fuel in their fuel-fired reheating furnaces. Because natural gas pipelines are only located in part of southwest Sweden, it is not common for Swedish steel companies to use natural gas as fuel. However, recently many Swedish steel companies have investigated the option of using liquefied natural gas (LNG), which can be transported by boat, train and truck. 


\section{The system studied}

\subsection{Case company}

The steel plant investigated in this case study is Sandvik $A B$, which has its production facilities in Sandviken in central Sweden. Sandvik $A B$ is a scrap-based steel plant and produces steel in an electric arc furnace, an AOD converter and a ladle furnace, each with a charge-weight of 75 tonnes.

Sandvik $A B$ has a number of LPG-fired reheating furnaces with the purpose of heating the steel before processing into products such as wire, tubes, and sheets. The furnaces are of varying ages, with installation dates ranging from 1971 to 2010. Furthermore, the burners are of different types: cold air burners (conventional), regenerative ${ }^{1}$ burners and recuperative ${ }^{2}$ burners. The reheating furnaces at Sandvik use approximately $1008 \mathrm{TJ}$ of LPG annually and installed power in the furnaces varies between $1 \mathrm{MW}$ and 18 $\mathrm{MW}$ with the majority between $2 \mathrm{MW}$ and $4 \mathrm{MW}$. [20]

Because the analysis does not include costs for site-specific investments, such as investment in new burners in the reheating furnaces, a new gas distribution system and an exhaust gas cleaning system, the steel plant used in the case can be used as a general example of a steel plant with the specified fuel demand.

\subsection{System description}

In the study three different systems were studied: 1) business as usual; 2) investment in a stand-alone biomass gasifier and replacement of LPG with bio-SNG as fuel in reheating furnaces; and 3) investment in a biomass gasifier, supplied with oxygen from the steel plant's distribution system, and replacement of LPG with bio-SNG as fuel in reheating furnaces. All of Sandvik's major LPG-fuelled reheating furnaces were included in the case study. These furnaces consume $80 \%$ of Sandvik's annual demand for LPG in reheating furnaces. The original system, in which LPG is used as fuel in the reheating furnaces, was compared with the systems in which the steel plant has invested in a biomass gasifier and bio-SNG replaces LPG as fuel.

A circulating fluidized bed gasifier was chosen as gasification technology, because it is suitable for gasification of biomass. The design results in excellent mixing and uniform temperature in the reactor; hence, the process is rather insensitive to fuel quality and the risk for fuel agglomeration is reduced. Fluidized bed gasification has higher efficiency and produces syngas with higher heating value than fixedbed gasification. [15] The specifications of the biomass gasifier chosen for this study were defined within the Biokombi Rya project [21]. The gasifier is a pressurised, oxygen-blown circulating fluidized bed (CFB) gasifier with a gas cleaning system comprising a high temperature filter and catalytic tar reforming technology. The gas cleaning is followed by water-gas shift and methanation. In the methanation process, syngas is converted into bio-SNG. Furthermore, an air separation unit (ASU) and a steam turbine are included in the gasification system to produce oxygen and electricity for the bio-SNG production process. The steam for the turbine is generated in the gas cooling processes in the gasification and methanation system. A system without an ASU was also analysed. In this case, the oxygen for the gasification system is purchased and supplied through the steel plant's distribution system.

The steel plant's demand for fuel to reheating furnaces is not constant and during the summer there is no production. Therefore the biomass gasifier would be turned off for four weeks. The gasifier was assumed to operate at constant bio-SNG output for $8000 \mathrm{~h} /$ year and a gas storage tank was assumed to hold the gas before distribution to furnaces. In order to supply adequate fuel to Sandvik AB in Sandviken $28 \mathrm{MW}$ bio-

\footnotetext{
${ }^{1}$ In regenerative burners, air and flue gases alternately pass through a ceramic material. The ceramic material is heated by the hot flue gases, and the air is then pre-heated by the ceramic material.

${ }^{2}$ In recuperative burners, the air is pre-heated by hot flue gases in a heat exchanger where air and flue gases flow on opposite sides of a heat-conducting material.
} 
SNG, $8000 \mathrm{~h} /$ year is required. The gasification system produces excess heat suitable for district heating (DH). In the study, it was assumed that it is possible to sell heat to the DH system during all operation hours (i.e., $8000 \mathrm{~h} /$ year). Fig. 1 shows a flow chart of the system studied.

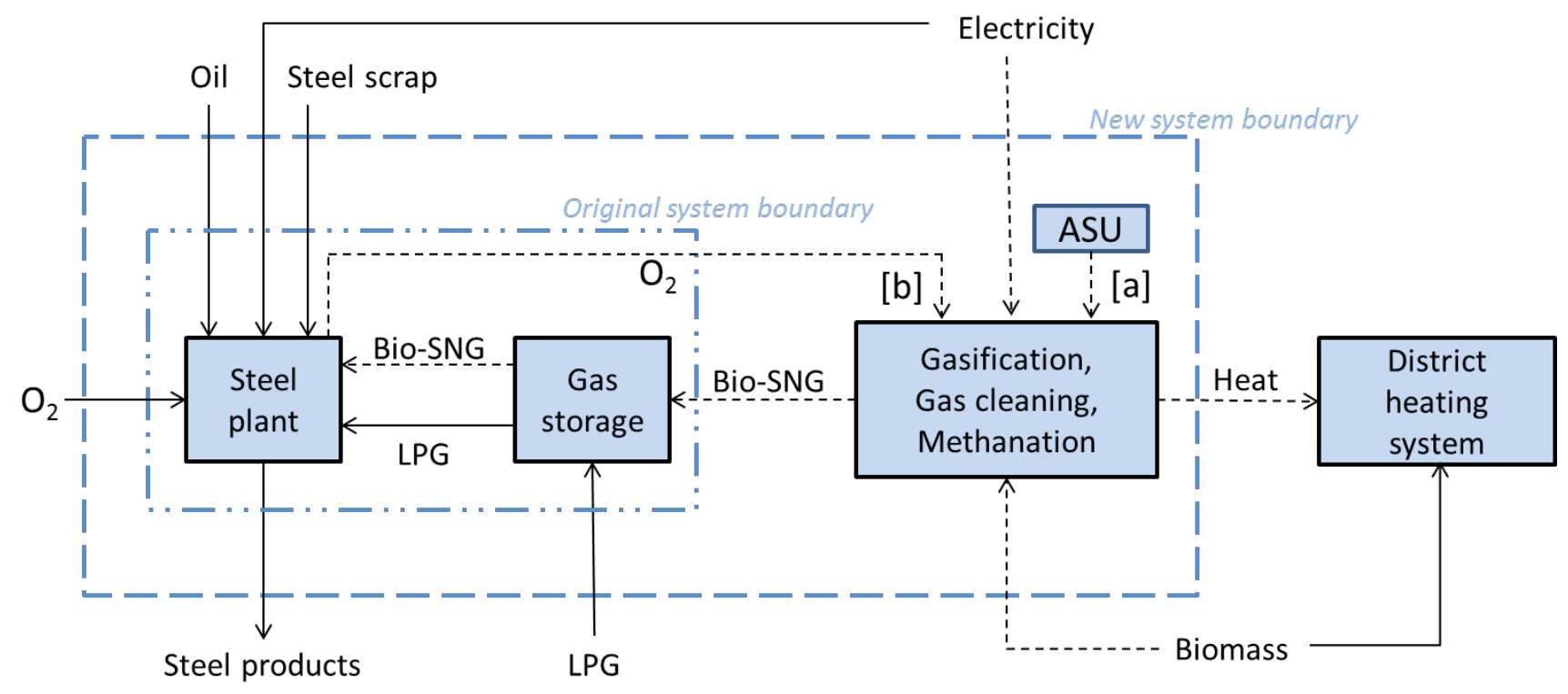

Fig. 1. The system studied. Dotted arrows indicate the new energy flows introduced when a biomass gasification and methanation system produces fuel for the steel plant: [a] is a system in which the gasifier's oxygen demand is supplied by its own air separation unit (ASU) and [b] is a system in which the oxygen demand is supplied by the steel plant's oxygen distribution network.

\section{Methodology}

\subsection{Energy market scenarios}

Consistent energy market scenarios were used to evaluate the future economic potential in the case of a steel plant investing in a biomass gasifier. Using scenarios made it possible to evaluate future or long-term investments. The scenarios were generated by the Energy Price and Carbon Balance Scenarios tool (the ENPAC tool) version 1.8. The tool was developed at Chalmers University and a thorough description of the tool was presented by Axelsson and Harvey [22] and Axelsson et al. [23]. The ENPAC tool has been used in previous studies (see, e.g., [11, 12, 24-26]). One scenario with prices from 2011 and four future energy market scenarios predicting different possible cornerstones of the energy market in 2030 were used in the analysis. In the scenarios, prices of biomass, fossil fuels, electricity and $\mathrm{CO}_{2}$ were varied. The cost of electricity production is the total generation cost, including power plant investment cost for a new base load plant, and this is referred to as the build margin technology. It was assumed that in the time period analysed, the build margin technology for electricity generation could be a coal condensing power plant or a natural gas combined cycle (NGCC), and the ENPAC tool could choose between these two as the build margin technology.

Two DH systems were considered, both of which are based on biofuel: one was a Swedish DH system in which most of the heat is produced in bio-fuelled heat-only boilers (HOB), hereafter called a bio-HOB system. The other was a Swedish DH system in which the most of the heat is produced in bio-fuelled combined heat and power (CHP) plants, hereafter called a bio-CHP system. The HOB system and the CHP system were assumed to represent a small Swedish heat system and a large Swedish heat system, respectively. The value of delivering industrial excess heat to a DH system was set by the heat prices that a new heat supplier would have to compete with. The specifications of the scenarios can be seen in Table 1. 
Table 1. Prices and $\mathrm{CO}_{2}$ emission factors used in the energy market scenarios. The prices are end-user prices, including $\mathrm{CO}_{2}$ charge. EUR/SEK=8.88

\begin{tabular}{|c|c|c|c|c|c|c|}
\hline Scenario & & $\begin{array}{l}\text { Current price } \\
\text { levels }\end{array}$ & $1^{\mathrm{a}}$ & $2^{b}$ & $3^{c}$ & $4^{d}$ \\
\hline Fossil fuel price level & & 2011 & High & Low & High & Low \\
\hline $\mathrm{CO}_{2}$ emission charge & & 2011 & Low & Low & High & High \\
\hline \multicolumn{7}{|l|}{ End user prices } \\
\hline $\mathrm{CO}_{2}$ & EUR/tonne & $8^{e}$ & 30 & 30 & 72 & 72 \\
\hline LPG & $E U R / G J_{\text {fuel }}$ & 15 & 29 & 26 & 31 & 26 \\
\hline Wood pellets & $E U R / G J_{\text {fuel }}$ & 8 & 15 & 13 & 17 & 16 \\
\hline Electricity & $\mathrm{EUR} / \mathrm{MWh}_{\mathrm{el}}$ & $47^{f}$ & 68 & 67 & 98 & 86 \\
\hline \multicolumn{7}{|c|}{ Industrial excess heat, sales price } \\
\hline \multicolumn{7}{|l|}{ Bio-HOB in Sweden } \\
\hline \multirow[t]{2}{*}{ Bio-CHP in Sweden } & $E U R / G J_{\text {heat }}$ & $12^{\mathrm{g}}$ & 12 & 11 & 14 & 13 \\
\hline & $E U R / G J_{\text {heat }}$ & & 6 & 4 & 4 & 4 \\
\hline $\mathrm{O}_{2}$ & EUR/tonne & 39 & 56 & 56 & 81 & 71 \\
\hline
\end{tabular}

$\mathrm{CO}_{2}$ emissions

LPG

$\mathrm{kg} \mathrm{CO} / \mathrm{GJ}_{\text {fuel }}$

68

$\begin{array}{llll}68 & 68 & 68 & 68\end{array}$

Biomass

Marginal user of biofuel FT

FT FT Coal Coal

$\mathrm{kg} \mathrm{CO} / \mathrm{GJ}_{\text {fuel }}$

32

$\begin{array}{llll}33 & 33 & 71 & 99\end{array}$

Electricity

Build margin

Coal

Coal Coal Coal NGCC

$$
\mathrm{kg} \mathrm{CO} / \mathrm{MWh}_{\mathrm{el}}
$$

809

$\begin{array}{llll}714 & 714 & 714 & 340\end{array}$

District heating

Bio-HOB in Sweden

$\mathrm{kg} \mathrm{CO} / \mathrm{GJ}_{\text {heat }}$

Bio-CHP in Sweden

$\mathrm{kg} \mathrm{CO} / \mathrm{GJ}_{\text {heat }}$

49

$\begin{array}{llll}41 & 41 & 101 & 101\end{array}$

$\begin{array}{lllll}14 & -6 & -6 & 66 & 98\end{array}$

${ }^{a}$ Fuel prices on the world market: Oil 135 USD/barrel, Natural gas 13 USD/Mbtu, Coal 116 USD/tonne. Source: Current policies scenario in World Energy Outlook 2011 [27].

${ }^{\mathrm{b}}$ Fuel prices on the world market: Oil 117 USD/barrel, Natural gas 12 USD/Mbtu, Coal 109 USD/tonne. Source: New policies scenario in [27].

${ }^{\mathrm{C}}$ Fuel prices on the world market: Oil 135 USD/barrel, Natural gas 13 USD/Mbtu, Coal 115 USD/tonne. This scenario is added in order to include a scenario with high fossil fuel prices and high $\mathrm{CO}_{2}$ emission charge.

${ }^{d}$ Fuel prices on the world market: Oil 97 USD/barrel, Natural gas 10 USD/Mbtu, Coal 74 USD/tonne. Source: 450 scenario in [27].

${ }^{\mathrm{e}}$ Purchase price of EU-ETS permits.

${ }^{f}$ Average Elspot price Nord Pool, 2011. 
${ }^{8}$ Sales price of heat to DH system is set at $75 \%$ of purchase price. (Correspondence with the local DH distributer Sandviken Energi)

Global $\mathrm{CO}_{2}$ emissions associated with the utilisation of the energy carriers were considered. With regard to $\mathrm{CO}_{2}$ emissions, a system with a European perspective was evaluated. This means that the steel plant's energy system affects the surrounding system. If an electricity producer increases or decreases its production, the marginal electricity producer decreases or increases its production by an equal amount and this affects global $\mathrm{CO}_{2}$ emissions. If biomass is considered an unlimited resource and replanting is performed at the same rate as harvesting, biomass utilisation is $\mathrm{CO}_{2}$ neutral. However, in this study biomass is considered a limited resource on the global market and $\mathrm{CO}_{2}$ emissions are allocated to the biomass user. This means that if a new biomass purchaser enters the market, the marginal biomass user will reduce its use of biomass by an amount corresponding to the amount purchased by the new player. Producers of transportation biofuel and coal power plants with wood fuel co-firing were considered the most likely marginal biomass users in the future [22]. Therefore the ENPAC tool could choose between two marginal biomass users: a producer of FT diesel from biomass or a coal power plant with wood fuel co-firing. FT diesel was assumed to replace fossil diesel in the transport sector. Life cycle assessment (LCA) was used to calculate $\mathrm{CO}_{2}$ emissions; these $\mathrm{CO}_{2}$ emissions factors can be found in Table 1. A more thorough description of this system perspective can be found in Heyne and Harvey [24].

\subsection{Economic evaluation and $\mathrm{CO}_{2}$ emissions evaluation}

Two systems were compared with the existing system in which the reheating furnaces are fuelled with LPG: 1) a system in which the steel plant has invested in a biomass gasifier with an ASU and the reheating furnaces are fuelled with bio-SNG from the gasifier and 2) a system in which the steel plant has invested in a biomass gasifier without an ASU and the reheating furnaces are fuelled with bio-SNG from the gasifier. The total system costs for these systems were compared to find investment opportunity for required modifications in the steel plant, (e.g., investment in new burners in the heating furnaces, in a new gas distribution system and in an exhaust gas cleaning system). The difference in total system cost between the systems was calculated for the scenario with current price levels and the four future energy market scenarios according to Equation 1

$N A P=C_{\text {system LPG }}-C_{\text {system, }, N G}=\left(C_{L P G}+C_{e l, v a p}\right)-\left(C_{\text {invBG }}+C_{O \& M, B G}+C_{\text {biomass }}+C_{e l, B G}-R_{D H}\right)$

Equation 1

where NAP is the net annual profit; $C_{\mathrm{LPG}}$ is the annual cost for purchased LPG; $\mathrm{C}_{\mathrm{el}, \text { vap }}$ is the annual cost for electricity for vaporisation of LPG; $C_{\text {invBG }}$ is the annual capital cost with regard to investment in a biomass gasification system; $C_{O \& M, B G}$ is the annual operation and maintenance (O\&M) costs for the biomass gasification system; $C_{\text {biomass }}$ is the annual cost for biomass to the gasifier; $C_{\mathrm{el}, \mathrm{BG}}$ is the annual cost for electricity to the gasification system; and $\mathrm{R}_{\mathrm{DH}}$ is the annual revenue for heat sold to a DH system. In the calculations, the value of excess heat delivered to the DH system was set by a Swedish HOB system. The investment cost was discounted using the annuity method. A discount rate of $6 \%$ and a 20 -year discount period were used, which generated a capital recovery factor (CRF) of $8.7 \%$.

The effects on global $\mathrm{CO}_{2}$ emissions if Sandvik $A B$ invests in a biomass gasification system and substitutes LPG with bio-SNG were evaluated by comparing annual emissions from the existing system with annual emissions from the new system. Calculations were done using Equation 2.

$\Delta \mathrm{CO}_{2}=\mathrm{EM}_{\text {system LPG }}-\mathrm{EM}_{\text {system }, \mathrm{SNG}}=\left(\mathrm{EM}_{\mathrm{LPG}}+\mathrm{EM}_{\mathrm{el}, \mathrm{vap}}\right)-\left(\mathrm{EM}_{\text {biomass }}+\mathrm{EM}_{\mathrm{el}}-\mathrm{EM}_{\mathrm{DH}}\right)$

Equation 2

where $\mathrm{EM}_{\mathrm{LPG}}$ is the annual $\mathrm{CO}_{2}$ emissions from burning $L P G$; $E M_{\mathrm{el}, \mathrm{vap}}$ is the annual $\mathrm{CO}_{2}$ emissions from the electricity used to evaporate LPG; $\mathrm{EM}_{\text {biomass }}$ is the annual $\mathrm{CO}_{2}$ emissions allocated to the biomass user; $\mathrm{EM}_{\mathrm{el}}$ is the annual $\mathrm{CO}_{2}$ emissions from electricity used in the gasification and methanation system; and $\mathrm{EM}_{\mathrm{DH}}$ is the annual $\mathrm{CO}_{2}$ emissions associated with $\mathrm{DH}$ production. 


\subsubsection{Input data}

Input data to the analysis was investment cost and O\&M costs for a $45 \mathrm{MW}_{\text {th }}$ gasification and methanation system, energy prices and $\mathrm{CO}_{2}$ emissions charge. The investment costs include costs for equipment, process automation, process instrumentation, process electrification, piping in the plant, building and civil works for gasification plant and fuel handling, engineering, commissioning and start-up and management. The gasifier operates at $43 \mathrm{MW}_{\text {th }}$ with an operating time of $8000 \mathrm{~h} /$ year. The current fuel demand at Sandvik $A B$ would be supplied by a $43 \mathrm{MW}_{\text {th }}$ gasifier, but investment in a $45 \mathrm{MW}_{\text {th }}$ gasifier was calculated in case of increased steel production and fuel demand in the future. The performance data of the gasification system is shown in Table 2.

Table 2. Performance data for a $45 \mathrm{MW}_{\text {th }}$ gasification system with bio-SNG production, operating at 43 $M W_{t h}$. The system includes a CFB gasifier, a gas cleaning system, a methanation reactor, an air separation unit (ASU) and a steam turbine. Data given in brackets is for a system without ASU. Data is based on [21].

\begin{tabular}{|c|c|c|c|c|c|c|c|c|}
\hline \multirow{2}{*}{$\begin{array}{l}\text { Biomass input } \\
\left(\mathrm{MW}_{\text {th }}\right)\end{array}$} & \multirow{2}{*}{$\begin{array}{l}\text { SNG output } \\
\text { (MW } \text { bio-SNG })\end{array}$} & \multicolumn{3}{|c|}{ Electricity $\left(\mathrm{MW}_{\mathrm{el}}\right)$} & \multirow{2}{*}{$\begin{array}{l}\mathrm{DH} \\
\text { production } \\
\left(\mathrm{MW}_{\text {heat }}\right)\end{array}$} & \multirow[b]{2}{*}{ SNG } & \multicolumn{2}{|l|}{ Efficiency } \\
\hline & & Demand & Production & $\begin{array}{l}\text { Net } \\
\text { production }\end{array}$ & & & Electricity & $\mathrm{DH}$ \\
\hline 43 & 27.6 & $3.2(1.7)$ & $2.4(2.5)$ & $-0.8(0.8)$ & 10.2 & 0.64 & $\begin{array}{l}-0.02 \\
(0.02)\end{array}$ & 0.24 \\
\hline
\end{tabular}

Investment data for the gasification system was taken from Chalmers Energy Centre [21] and the data was adjusted to the base year $2010^{3}$, using the Chemical Engineering Plant Cost Index [28]. The gasification system was assumed to be scalable according to the general equation, Equation 3 ,

$$
\frac{c}{c_{b a s e}}=\left[\frac{s}{s_{b a s e}}\right]^{R}
$$

Equation 3

where $\mathrm{C}$ and $\mathrm{S}$ are investment cost and plant capacity for a new plant and $\mathrm{C}_{\text {base }}$ and $\mathrm{S}_{\text {base }}$ are investment cost and plant capacity for a plant with known investment cost for a certain capacity. The scale-up factor, $R$, was set to 0.7. This scale-up factor is an average value for chemical processing plants [29]. The economic data for investment and O\&M costs can be seen in Table 3.

Table 3. Economic data for investment in a $45 \mathrm{MW}_{\text {th }}$ gasification system which produces bio-SNG from wood pellets. The system includes a CFB gasifier, a gas cleaning system, a methanation reactor, an air separation unit (ASU) and a steam turbine. Data given in brackets is for a system without ASU. Data is based on [21].

\begin{tabular}{|c|c|c|}
\hline Economy $^{a}$ (2011) & $\begin{array}{l}45 \mathrm{MW}_{\mathrm{th}} \\
\text { wood pellet }\end{array}$ & \\
\hline \multicolumn{3}{|l|}{ Investment } \\
\hline TIC (total investment cost) & $75.5(67.5)$ & MEUR \\
\hline Capital $\operatorname{cost}^{b}(8.7 \%$ of TIC) & $6.6(5.9)$ & MEUR/year \\
\hline
\end{tabular}

${ }^{3}$ The base year in the ENPAC tool, version 1.8, is 2010. 


\section{Operation and maintenance costs}
O\&M, fixed cost (3.5\% of TIC/year)
$2.6(2.4)$
MEUR/year
O\&M, variable cost
1.0
EUR/GJ fuel ${ }_{\text {input }}$

${ }^{a} \mathrm{EUR} / \mathrm{SEK}=8.88,{ }^{b}$ Discount rate is $6 \%$ and discount period is 20 years.

\subsection{Primary energy}

In order to analyse the resource efficiency of producing bio-SNG from wood pellets, calculations of primary energy use were conducted. Primary energy is an energy source that has not been subjected to any conversion or transformation process (e.g., natural gas, coal and crude oil). During energy conversion and transformation processes there may be losses and the higher the loss, the higher the primary energy use. The primary energy factor (PEF) of an energy carrier is the amount of primary energy used to produce one unit of that carrier, taking into consideration a life cycle perspective where energy for processing, transport, conversion and distribution is included. PEF for the energy carriers of interest for this study can be seen in Table 4.

Table 4. Primary energy factors for the energy carriers of interest.

\begin{tabular}{ll}
\hline & $\begin{array}{l}\text { Primary energy factor } \\
\text { (MJ/MJ fuel or electricity) }\end{array}$ \\
\hline Energy carrier & $1.3^{\mathrm{a}}$ \\
\hline WPG & $1.3^{\mathrm{b}}, 1.1^{\mathrm{c}}, 1.15^{\mathrm{d}}, 1.2^{\mathrm{e}}$ \\
Wood pellets & \\
Electricity (coal & \\
power plant) & $3.0^{\mathrm{a}}, 2.7^{\mathrm{b}}$ \\
Industrial excess & \\
heat to DH system & $0.03^{\mathrm{d}}$ \\
& \\
DH (Bio-HOB) & $1.4^{\mathrm{a}}$ \\
\hline${ }^{\mathrm{a}}[30]$ & \\
${ }^{\mathrm{b}}[31]$ & \\
${ }^{\mathrm{c}}[32]$ & \\
${ }^{\mathrm{d}}[33]$ & \\
${ }^{\mathrm{e}}[34]$ &
\end{tabular}

The reported primary energy use factor for industrial excess heat delivery to a DH system includes the energy used to pump the heat from the industry to the DH system. In the calculations of primary energy use in this study, a PEF of 1.2 was used for wood pellets and a PEF of 2.7 was used for electricity.

\subsection{Sensitivity analysis on economy}

The scenario methodology includes a sensitivity analysis of energy prices and $\mathrm{CO}_{2}$ emissions charge. The NAP also depends on the capital costs with regard to the biomass gasification system. To extend the sensitivity analysis, the discount rate was increased from $6 \%$ to $12 \%$. The sensitivity analysis also included 
two cases in which the investment cost for the gasification and methanation system was reduced by $20 \%$ and $40 \%$. Because future fuel demand may be higher if steel production increases, the sensitivity analysis included a $20 \%$ higher fuel demand and an increase in the size of the gasification system from $45 \mathrm{MW}_{\text {th }}$ to $55 \mathrm{MW}_{\text {th. }}$ In this case, the gasifier was assumed to operate at $53 \mathrm{MW}_{\text {th }}$ biomass input $8000 \mathrm{~h} / \mathrm{year}$. The economic data for the sensitivity analysis can be seen in Table 5 . In the base case, it was assumed that it would be possible to sell heat to the DH system $8000 \mathrm{~h} /$ year; since heat demand is reduced during the spring and summer the sensitivity analysis included a case where heat was sold for $5000 \mathrm{~h} /$ year. The sensitivity analysis was performed only on the system where an ASU is included in the gasification system.

Table 5. Economic data for the sensitivity analysis of investment costs. The discount rate is increased to $12 \%$ and/or the fuel demand at Sandvik $A B$ is increased by $20 \%$. In addition, total investment cost is reduced by 20 and $40 \%$ respectively. Data is based on [21].

\begin{tabular}{|c|c|c|c|c|c|c|}
\hline $\begin{array}{l}\text { Economy }^{a} \\
(2011)\end{array}$ & $\begin{array}{l}45 \mathrm{MW}_{\text {th }} \\
\text { (Discount } \\
\text { rate } 12 \% \text { ) }\end{array}$ & $\begin{array}{l}55 \mathrm{MW}_{\text {th }} \\
\text { (Discount } \\
\text { rate } 6 \% \text { ) }\end{array}$ & $\begin{array}{l}55 \mathrm{MW}_{\text {th }} \\
\text { (Discount } \\
\text { rate } 12 \% \text { ) }\end{array}$ & $\begin{array}{l}45 \mathrm{MW}_{\text {th }} \\
\text { (Discount } \\
\text { rate } 6 \% \text { ) }\end{array}$ & $\begin{array}{l}45 \mathrm{MW}_{\text {th }} \\
\text { (Discount } \\
\text { rate } 6 \% \text { ) }\end{array}$ & \\
\hline \multicolumn{7}{|l|}{ Investment } \\
\hline $\begin{array}{l}\text { TIC (total } \\
\text { investment cost) }\end{array}$ & 75.5 & 86.9 & 86.9 & 60.4 & 45.3 & MEUR \\
\hline Capital cost ${ }^{b}$ & 10.1 & 7.6 & 11.6 & 5.3 & 3.9 & MEUR/year \\
\hline \multicolumn{7}{|l|}{$\begin{array}{l}\text { Operation and } \\
\text { maintenance } \\
\text { costs }\end{array}$} \\
\hline $\begin{array}{l}\text { O\&M, fixed cost } \\
\text { (3.5\% of } \\
\text { TIC/year) }\end{array}$ & 2.6 & 3.0 & 3.0 & 2.1 & 1.6 & MEUR/year \\
\hline $\begin{array}{l}\text { O\&M, variable } \\
\text { cost }\end{array}$ & 1.0 & 1.0 & 1.0 & 1.0 & 1.0 & $\begin{array}{l}\text { EUR/GJ } \\
\text { biomass input }\end{array}$ \\
\hline
\end{tabular}

${ }^{\mathrm{a} E U R / S E K}=8.88$.

${ }^{\mathrm{b}}$ Discount period is 20 years.

\section{Results and discussion}

In this section the results with regard to economy, primary energy use and global $\mathrm{CO}_{2}$ emissions are presented and discussed.

\subsection{Economy}

The analysis shows that investment in a biomass gasification system and substitution of LPG with bio-SNG would not be profitable in any of the scenarios (see Fig. 2). Scenario 4, which has the low fossil fuel prices and high $\mathrm{CO}_{2}$ emission charge, was the one with the highest increase in annual costs. Scenario 1 and 3 showed the smallest difference between the total system costs. These scenarios have high fossil fuel prices, but the $\mathrm{CO}_{2}$ emission charge level is low in scenario 1 and high in scenario 3 . If the oxygen to the gasification system were supplied through the steel plant's oxygen distribution system, the production costs for bio-SNG would be less in all scenarios. The conclusion is that it is more economically favourable to invest in a gasification system without ASU and to purchase oxygen from the steel plant's oxygen supplier. 


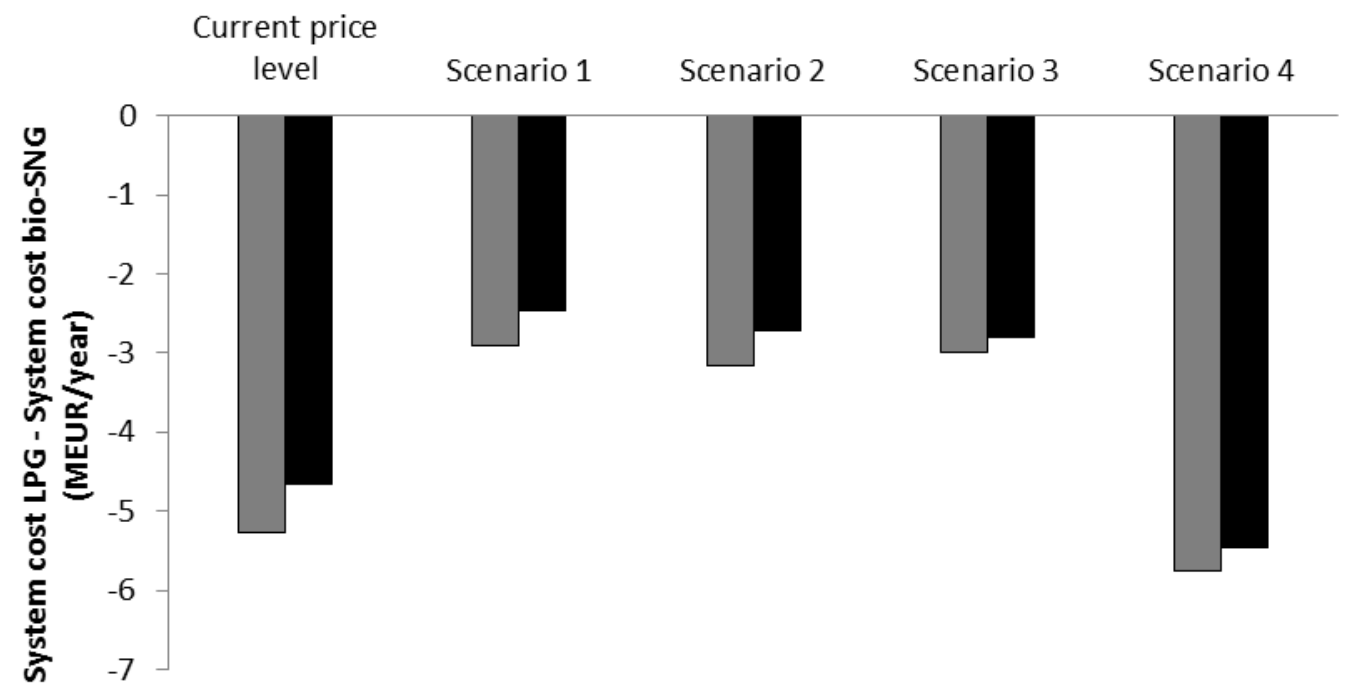

$\square 45$ MWth gasifier, with ASU

45 MWth gasifier, without ASU

Fig. 2. NAP for a $45 \mathrm{MW}$ th biomass gasifier at Sandvik $A B$ in Sandviken, Sweden, which operates at a biomass input of $43 \mathrm{MW}_{\text {th }}$ for $8000 \mathrm{~h} /$ year. The negative values indicate that investment in a biomass gasification and methanation system and fuel conversion would not be profitable for Sandvik $A B$.

For the scenario with current prices, the total production cost for bio-SNG, including the equipment's depreciation, was $22 \mathrm{EUR} / \mathrm{GJ}_{S \mathrm{SG}}$ with an ASU and $21 \mathrm{EUR} / \mathrm{GJ}_{\mathrm{SNG}}$ without an ASU. This is in the range of estimated production costs for bio-SNG presented by Gassner et al. [35]. Fig. 3 shows the costs for bio-SNG and LPG in all scenarios. It can be seen that high fossil fuel prices and high $\mathrm{CO}_{2}$ emission charge (scenario 3 ) would result in high costs for both LPG and bio-SNG. This is not unexpected as high fossil fuel prices and high $\mathrm{CO}_{2}$ charge would provide incentives to use biomass instead of fossil fuels. One could argue that the consequences of increased demand for biomass and competition for the resource would be rising biomass prices, which would result in increased production costs for bio-SNG. When analysing the future market scenarios, the lowest production cost for bio-SNG occurred in scenario 2, where fossil fuel prices are low and $\mathrm{CO}_{2}$ emission charge is low. It can also be noted that scenarios 1 and 3 had the biggest difference between LPG price and biomass price. In conclusion, profitability is highly dependent on biomass and LPG prices. A low biomass price in relation to a high LPG price would favour substitution of LPG with bio-SNG. If the wood pellets price was as specified in the scenarios, the LPG price would have to be at least 14-18 EUR/GJ higher than wood pellets price to get a positive NAP. 


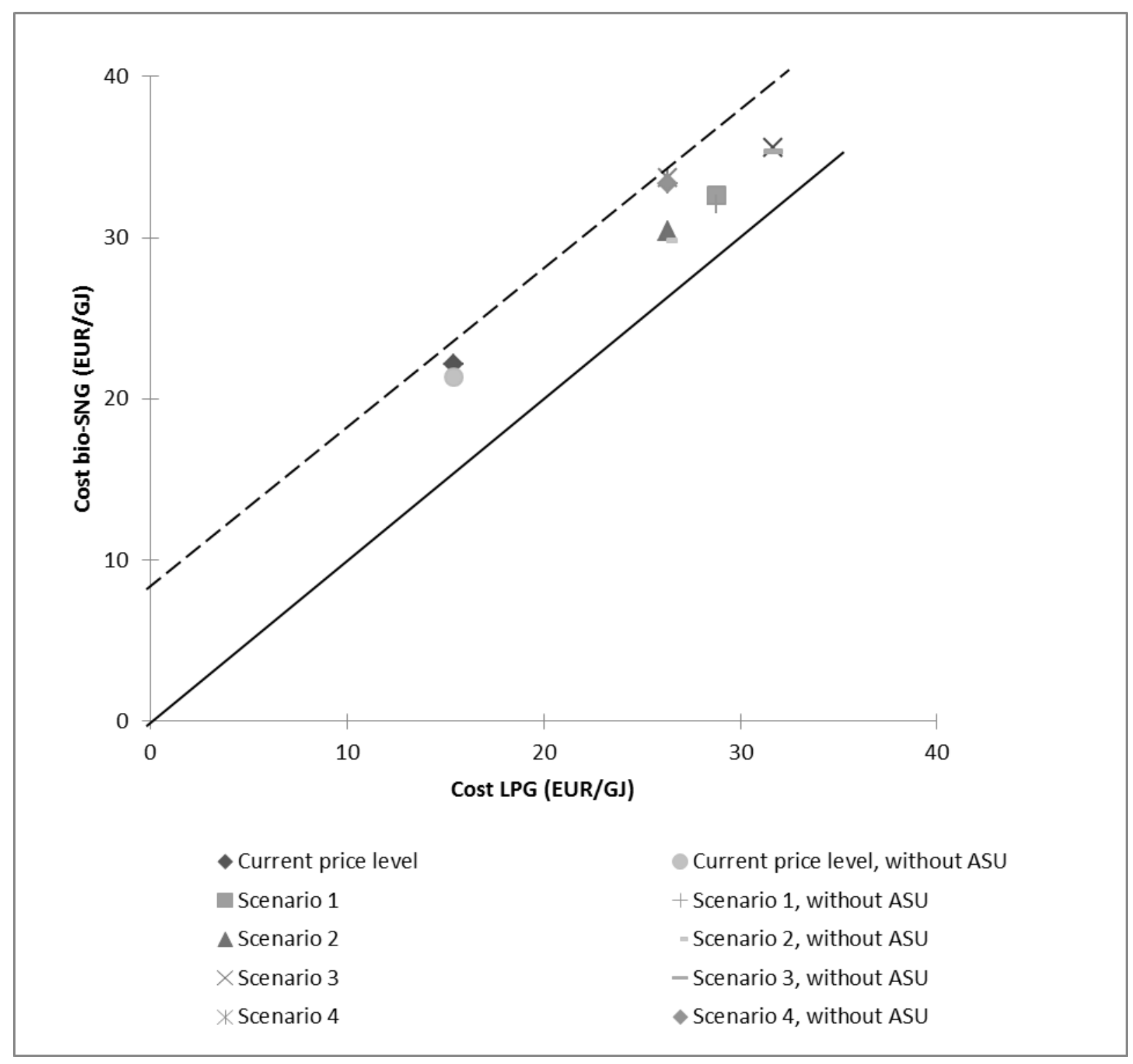

Fig. 3. Cost for $L P G$ (including cost for vaporisation of the gas and $\mathrm{CO}_{2}$ emission permits) and production cost for bio-SNG. Symbols above the solid diagonal line represent scenarios where the production cost for bio$S N G$ is higher than the cost for LPG. The dashed line shows the impact of a policy support of $8 \mathrm{EUR} / G \mathrm{~J}_{\text {bio-SNG. }}$.

It can be discussed that in a transition period before biomass gasification technology is fully commercialised, a fuel conversion from LPG to fossil natural gas could be advantageous in terms of reduced $\mathrm{CO}_{2}$ emissions. Because fossil natural gas and bio-SNG are fully exchangeable, the steel plant is equipped for a future integration with a biomass gasification system. For industrial consumers, the end-user price of natural gas in Sweden was 14 EUR/GJ in 2012 [36]. It can be speculated that even if production costs for bio-SNG are higher than the purchase price of natural gas, bio-SNG could be of interest for users situated in places where natural gas is not available. The production cost of bio-SNG is highly dependent on biomass price. In Sweden, wood pellet prices have increased since 2007 [37] and the CHP plants' willingness to pay these prices is high because of the Swedish subsidies for production of electricity from biomass. However, it is uncertain whether these subsidies will persist until 2030, and prices may fall.

The costs for modifications required in the steel plant were not included in the analysis. These costs are site-specific and may form a significant portion of the total cost. A rough estimate of the costs for reconstruction of reheating furnaces and a new gas distribution system at Sandvik AB in Sandviken is 11 MEUR [38]. Therefore, to make bio-SNG production viable there is a need for policy measures that support 
biofuel production, which other researchers also emphasized [24, 26, 39, 40]. In 2009, the average tax reduction in EU for bio-diesel was 7 EUR/GJ [41]. If a corresponding tax reduction could be adopted for input of biofuels in the production of materials such as steel, it could be profitable for the process industry to convert from fossil fuels to biofuels. The results show that a policy support of at least 8 EUR/GJ for produced bio-SNG would level the costs for bio-SNG to below the costs for LPG in all scenarios. An investment grant could also make investment in a facility for production of bio-SNG and fuel substitution profitable. The lowest level of policy support required to get a positive NAP is shown in Table 6.

Table 6. Lowest level of policy support for production of bio-SNG to achieve a positive NAP.

\begin{tabular}{lccccc}
\hline & $\begin{array}{c}\text { Current price } \\
\text { level }\end{array}$ & Scenario 1 & Scenario 2 & Scenario 3 & Scenario 4 \\
\hline $\begin{array}{l}\text { Policy support for renewable fuel } \\
\text { (EUR/GJ Jio-SNG) }\end{array}$ & 6.7 & 3.8 & 4.1 & 3.9 & 7.4 \\
Investment grant (\% of TIC) & 79 & 44 & 48 & 45 & 87 \\
\hline
\end{tabular}

\subsection{Sensitivity analysis on economy}

The results of the sensitivity analysis (Fig. 4) show that the gasification and methanation system is subject to an economy of scale, which has an impact on production cost for bio-SNG. When the production of bioSNG was increased by $20 \%$, production cost for bio-SNG was reduced by $2-4 \%$, depending on the scenario, and this reduction equals a reduction of approximately $1 \mathrm{EUR} / \mathrm{GJ}_{\text {bio-SNG. }}$. However, despite the lower production cost, the cost for bio-SNG would be higher than the cost for LPG and, due to the higher fuel demand at Sandvik $A B$, the scenario with a $55 \mathrm{MW}_{\text {th }}$ gasifier implies a worse economic situation than the scenario with a $45 \mathrm{MW}_{\text {th }}$ gasifier. To further investigate the effects of economy of scale, it would be interesting to analyse the option to invest in a bigger gasifier and to convert the oil boilers, which produce process steam, to use bio-SNG. In keeping with this, it could be of interest to analyse investment in a large facility, where some of the bio-SNG produced can be sold to external consumers. Fahlén et al. [25] showed that a $240 \mathrm{MW}_{\text {th }}$ bio-SNG production plant with heat delivery to a $\mathrm{DH}$ system would be economically viable. Their study also concluded that it would be more profitable to use bio-SNG as vehicle fuel than to use bioSNG for electricity and heat production in a CHP plant.

The NAP for fuel substitution depends to a high degree on the discount rate for the investment. An increase in the discount rate from 6 to $12 \%$ has a significant impact on the capital costs and, consequently, creates an even more unfavourable condition for substituting LPG with bio-SNG. Another uncertainty in the analysis was the use of estimated investment costs for the gasification system; they were estimated because no commercial plants exist. In the future, if the concept is commercialised, costs may be lower, if for example, more efficient technology is used. In this study the investment cost had to be substantially reduced to get a positive NAP. A 40\% reduced investment cost could result in positive NAP in scenarios 1,2 and 3 (see Fig. 4). 


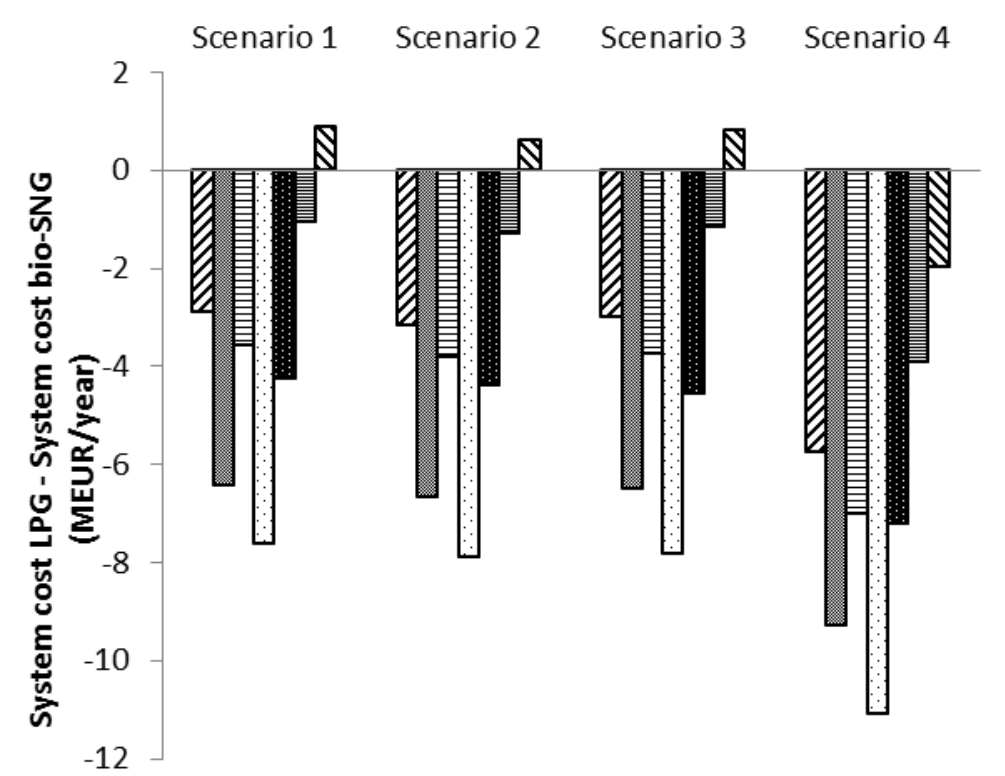

$\boldsymbol{\square} 45 \mathrm{MW}$ th gasifier, discount rate $6 \%$

45 MWth gasifier, discount rate $12 \%$

目55 MWth gasifier, discount rate $6 \%$

55 MWth gasifier, discount rate $12 \%$

$45 \mathrm{MWth}$ gasifier, discount rate $6 \%$, DH 5000h/year

$45 \mathrm{MWth}$ gasifier, discount rate $6 \%$, $20 \%$ reduced investment cost

$\mathbf{\nabla} 45$ MWth gasifier, discount rate $6 \%$, $40 \%$ reduced investment cost

Fig. 4. Sensitivity analysis of NAP for investment in a biomass gasifier at Sandvik AB in Sandviken, Sweden. The base case is a $45 \mathrm{MW}_{\text {th }}$ gasifier, a discount rate of $6 \%$ and a discount period of 20 years. The discount rate is increased to $12 \%$ and/or the fuel demand is increased by $20 \%$. Additionally, the heat delivery to the $\mathrm{DH}$ system is reduced from $8000 \mathrm{~h} /$ year to $5000 \mathrm{~h} /$ year and the investment cost is reduced by 20 and $40 \%$ respectively.

Delivering excess heat to the $\mathrm{DH}$ system also plays a noteworthy role in the economic evaluation. If heat delivery were reduced from $8000 \mathrm{~h} /$ year to $5000 \mathrm{~h} / \mathrm{year}$, the increase in annual costs in case of a fuel substitution would be $25-53 \%$ higher, depending on the scenario (see Fig. 4). This result points out the value of recovery of excess heat from the gasifier, in terms of profitability.

In future studies, it could be of interest to investigate biomass feedstock other than wood pellets as an input to the gasifier. It is possible to use fresh wood and forest residues (e.g., tops and branches); however, this requires pre-treatment of the biomass, such as chipping and drying. The steel production processes generate excess heat of different quality, and some of the heat could be used for drying biomass for the gasifier. However, the transportation costs of biomass would be higher than those for wood pellets because wood pellets have a higher energy density than untreated biomass. Steubing et al. [42], who have analysed drivers for economic performance of wood-based SNG production, ranked transportation costs as the third most important factor after revenue for sales of SNG, and SNG production costs. Because biomass is available in the region where Sandvik $A B$ is situated, transportation costs would be reasonable. Chipping of the biomass can be done at the site of felling, which would provide for volume-effective transportation of the wood to the gasifier. Another possible feedstock to investigate is waste wood from sawmills and pulp and paper industry. One gasification concept uses black liquor from chemical pulp mills as feedstock. Using waste from industry as feedstock results in resources being used more efficiently.

Fuel conversion from LPG to bio-SNG requires replacement of burners in reheating furnaces. When investing in new burners, the most energy-efficient burners on the market are likely to be chosen, which 
can result in reduced energy demand and, hence, reduced demand for bio-SNG. This must be considered in future extended economic analysis.

\subsection{Primary energy use and $\mathrm{CO}_{2}$ emissions evaluation}

Production of bio-SNG demands primary energy sources such as biomass, coal and oil. However, delivery of excess heat from the gasifier to the DH system would result in reduced utilisation of fuel in boilers in the DH system. The calculations show that PEF for bio-SNG was 1.6 MJ/MJ bio-SNG if excess heat from the gasifier were delivered to a bio-HOB DH system $8000 \mathrm{~h} /$ year. The total primary energy demand for production of the amount of bio-SNG that would satisfy the fuel demand in the reheating furnaces studied at Sandvik AB in Sandviken was consequently $1300 \mathrm{TJ} / \mathrm{year}$. This is approximately $20 \%$ more primary energy than if LPG were used. From a strict resource-efficient point of view, it is more advantageous to use LPG as fuel than to use bio-SNG.

Investments in a biomass gasification and methanation system and substitution of LPG with bio-SNG at Sandvik $\mathrm{AB}$ will affect global $\mathrm{CO}_{2}$ emissions. In evaluating $\mathrm{CO}_{2}$ emissions, only the system with an ASU was analysed because information about $\mathrm{CO}_{2}$ emissions from the external producer of $\mathrm{O}_{2}$ was not available at the time of the study. Fig. 5 shows how different biomass scenarios impact the outcome of the $\mathrm{CO}_{2}$ emissions evaluation. When the steel plant purchases biomass for the gasifier, the result would be increased fossil fuel utilisation in the transport or power sectors, depending on who the marginal biomass user is. In the scenario with current price level and scenarios 1 and 2, where the marginal biomass user is a producer of $\mathrm{FT}$ diesel, global $\mathrm{CO}_{2}$ emissions would decrease. Steubing et al. [43] confirmed that substitution of fossil fuels with bio-SNG for generation of heat would result in mitigation of global $\mathrm{CO}_{2}$ emissions. On the other hand, global $\mathrm{CO}_{2}$ emissions would increase in scenarios 3 and 4 , in which the marginal biomass user is a coal power plant. Replacing coal with biomass in coal power plants results in bigger reductions in global $\mathrm{CO}_{2}$ emissions than replacing fossil diesel with FT diesel in the transport sector. This explains the difference in the results between the scenarios with coal power plants as the marginal users of biomass and the scenarios with FT diesel production as the marginal user of biomass. These results are in keeping with results reported by Heyne and Harvey [24], who analysed global $\mathrm{CO}_{2}$ emissions from different bio-SNG production processes. The biggest increase in emissions can be seen in scenario 3 , where the marginal electricity producer is a coal power plant. The increase in global $\mathrm{CO}_{2}$ emissions is bigger for scenario 3 than for scenario 4 because global $\mathrm{CO}_{2}$ emissions are larger for electricity generation in a coal power plant than in a NGCC plant. In conclusion, from a climate change perspective, the options for utilisation of biomass considered in this paper should be prioritised accordingly: 1) as fuel in coal power plant, 2) to produce bioSNG and substitute LPG as fuel in reheating furnaces and 3) to produce FT diesel to the transport sector. 


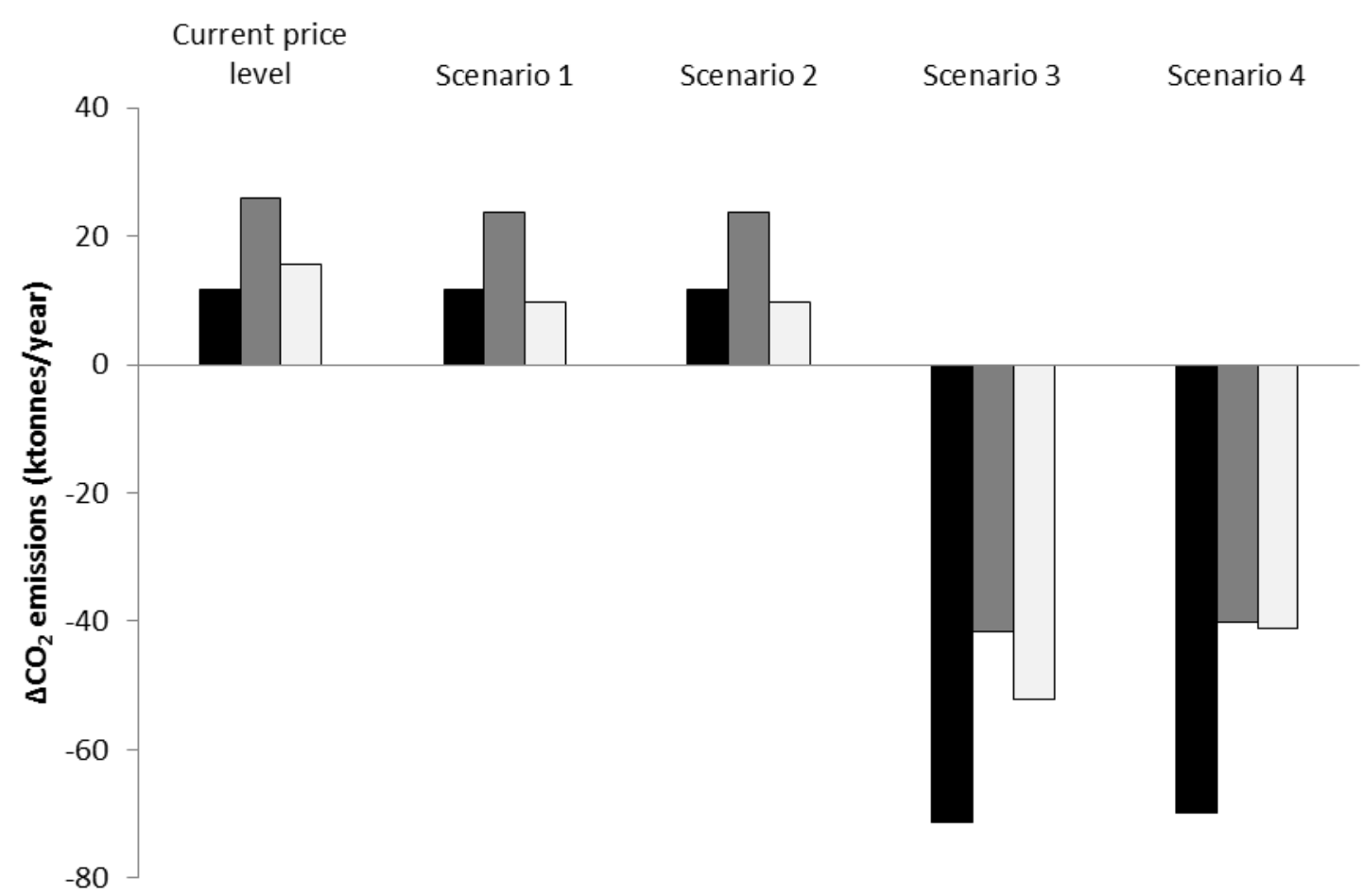

- No excess heat to DH network $\square$ Excess heat to bio-HOB system $\square$ Excess heat to bio-CHP system

Fig. 5. Effects on global $\mathrm{CO}_{2}$ emissions when a biomass gasification and methanation system produces fuel to Sandvik AB in Sandviken and LPG is substituted with bio-SNG. Positive values correspond to reduced global $\mathrm{CO}_{2}$ emissions.

The delivery of excess heat to a DH system reduces the fuel demand in the system and, consequently, makes biomass, which otherwise would be used for $\mathrm{DH}$ production, available for the marginal biomass user. This may lead to reduced fossil fuel use in the transport or power sectors. When heat is delivered from the gasifier to the $\mathrm{DH}$ system, the effect on global $\mathrm{CO}_{2}$ emissions depends on the type of heat production being replaced. If the excess heat replaces heat production in a Swedish bio-HOB system, the result is a decrease in global $\mathrm{CO}_{2}$ emissions (all scenarios). However, if the excess heat replaces heat production in a Swedish bio-CHP system, global $\mathrm{CO}_{2}$ emissions decrease when the marginal user of biomass is a coal power plant (scenario 3 and 4), but when the marginal biomass user is a producer of FT diesel (scenario 1 and 2) emissions increase. An exception was the scenario with current price levels where it would be advantageous to deliver excess heat to a bio-CHP system because the bio-CHP system of 2010 has a lower share of biomass compared to the bio-CHP system of 2030. The evaluation of how excess heat imported to $\mathrm{DH}$ systems affects global $\mathrm{CO}_{2}$ emissions showed that the $\mathrm{DH}$ systems based on bio-CHP are more sensitive to the choice of the marginal user of biomass than are the $\mathrm{DH}$ systems based on bio-HOB. This is because CHP plants need a larger fuel input compared to HOBs to produce the same amount of heat. Another important remark is that the excess heat which replaces the CHP production affects not only heat production in the $\mathrm{DH}$ system but also electricity production because heat and power are co-produced in the CHP plant. The reduced electricity production in the CHP plant is compensated for with marginal electricity production in coal power plants or NGCC plants. The fact that it would be unfavourable in terms of global $\mathrm{CO}_{2}$ emissions to deliver excess heat to a bio-CHP system can be seen as contradictory since heat recovery is often viewed as environmentally friendly and as one way to use energy resources more effectively. However, other environmental factors besides $\mathrm{CO}_{2}$ emissions and climate change have to be considered. In conclusion, the identification and choice of marginal biomass user, and marginal technologies for electricity and heat production are crucial for the analysis of global $\mathrm{CO}_{2}$ emissions. Mathiesen et al. [44] pointed out 
the importance of using different future scenarios with different marginal technologies when performing LCAs regarding energy use. To date, the market for biomass tends to be regional. In Sweden, where there are no coal power plants, the marginal biomass user in a regional market may be a producer of transportation fuel like FT diesel, but may also be a producer of DH. Lundmark et al. [45] concluded that the EU forest-based biomass markets are complex and there are several possible future scenarios for their development.

The results show that, if Sandvik AB in Sandviken substitutes LPG with bio-SNG, scenario 1 and 2 would result in reduced global $\mathrm{CO}_{2}$ emissions while scenario 3 and 4 would result in increased global $\mathrm{CO}_{2}$ emissions. However, from an economic point of view, scenario 1 and 3 were the least unfavourable. This shows the importance of including different perspectives when analysing best practice. It is important to evaluate and compare different pathways for biomass utilisation to find the optimal use of biomass in terms of economy and environment. This dilemma was discussed, for example, by Cowiea and Gardner [46] and Steubing et al. [47].

\section{Conclusions}

At current price levels, a fuel conversion at Sandvik AB in Sandviken from LPG to bio-SNG would result in higher annual cost. Since production of bio-SNG through biomass gasification and methanation is not yet a commercial technology, future energy market scenarios were used to analyse investment opportunities for the steel plant to invest in bio-SNG production. The analysis shows that none of the four future energy market scenarios would make it profitable for Sandvik AB in Sandviken to convert from LPG to bio-SNG.

The results from the analysis show that it would be more economically favourable to invest in a gasification system without an ASU and to purchase oxygen from the steel plant's oxygen supplier. At current price levels, the total production cost for bio-SNG for the cases with an ASU and without an ASU was 22 EUR/GJ bio-SNG $_{\text {and }} 21 \mathrm{EUR} / \mathrm{G} \mathrm{J}_{\text {bio-SNG, }}$, respectively. To get a positive NAP in all the scenarios, policy support of at least $8 \mathrm{EUR} / \mathrm{GJ}_{\text {bio-SNG }}$ would be needed.

In this study, the PEF for bio-SNG was $1.6 \mathrm{MJ} / \mathrm{MJ}$ bio-SNG, which is approximately $20 \%$ higher than the PEF for LPG. However, the primary energy of LPG is fossil fuels while the primary energy of bio-SNG is mostly renewables. The substitution of $\mathrm{LPG}$ with bio-SNG would result in reduced global $\mathrm{CO}_{2}$ emissions, if the marginal biomass user was a producer of FT diesel. However, if the marginal biomass user was a coal power plant with wood co-firing, global $\mathrm{CO}_{2}$ emissions would increase. Moreover, the delivery of excess heat to the DH system would not be advantageous in terms of $\mathrm{CO}_{2}$ emissions if the marginal user of biomass was a FT diesel production plant, the marginal electricity producer was a coal power plant and the DH system was a Swedish bio-CHP system. The increase in global $\mathrm{CO}_{2}$ emissions would be due to reduced electricity production in the bio-CHP plant and the resulting increased electricity production in a coal power plant.

\section{Acknowledgements}

The work has been carried out under the auspices of the Energy Systems Programme, which is financed by the Swedish Energy Agency. The work was co-financed by Göranssonska Fonden, which is a trust fund. The author wants to express gratitude to Magnus Karlsson and Danica Djuric llic at Linköping University for valuable comments on the paper. 


\section{References}

[1] IEA (International Energy Agency). Newsroom and Events 24 May 2012; 2012. Available at: www.iea.org/newsroomandevents/news/2012/may/name,27216,en.html. Accessed 2012-11-06.

[2] IEA (International Energy Agency). $\mathrm{CO}_{2}$ Emissions from Fuel Combustion - Highlights, 2012 Edition. Paris: OECD/IEA; 2012. Available at:

www.iea.org/publications/freepublications/publication/CO2emissionfromfuelcombustionHIGHLIGHTSMarc h2013.pdf. Accessed 2013-04-17.

[3] IEA (International Energy Agency). Addressing Climate Change: Policies and Measures Databases; 2012. Available at: www.iea.org/policiesandmeasures/climatechange/ Accessed 2012-11-06.

[4] EIA (U.S. Energy Information Administration). International Energy Outlook 2011. Report No: DOE/EIA0484; 2011. Available at: www.eia.gov

[5] ULCOS. Ultra Low CO2 Steelmaking. www.ulcos.org. Accessed 2012-10-18.

[6] Norgate T, Haque N, Somerville M, Jahanshahi S, Biomass as a Source of Renewable Carbon for Iron and Steelmaking. ISIJ International 2012;52(8):1472-1481.

[7] Hu Z, Zhang J, Zuo H, Tian M, Liu Z, Yang T. Substitution of Biomass for Coal and Coke in Ironmaking Process. Advanced Materials Research 2011;236-238:77-82.

[8] Mathieson JG, Rogers H, Somerville MA, Jahanshahi S. Reducing Net CO2 Emissions Using Charcoal as a Blast Furnace Tuyere Injectant. ISIJ International 2012;52(8):1489-1496.

[9] Norgate T, Langberg D. Environmental and Economic Aspects of Charcoal Use in Steelmaking. ISIJ International 2009;49(4):587-595.

[10] Johansson MT, Söderström M. Options for the Swedish Steel Industry - Energy Efficiency Measures and Fuel Conversion. Energy 2011;36:191-198.

[11] Johansson D, Franck P-Å, Berntsson T. Hydrogen production from biomass gasification in the oil refining industry - A system analysis. Energy 2012;38:212-227.

[12] Wetterlund E, Pettersson K, Harvey S. Systems analysis of integrating biomass gasification with pulp and paper productions - Effects on economic performance, $\mathrm{CO}_{2}$ emissions and energy use. Energy 2011;36:932-941.

[13] Isaksson J, Pettersson K, Mahmoudkhani M, Åsblad A, Bertsson T.

Integration of biomass gasification with a Scandinavian mechanical pulp and paper mill - Consequences for mass and energy balances and global $\mathrm{CO}_{2}$ emissions. Energy 2012;44:420-428.

[14] Buergler T, Di Donato A. Biomass gasification for DRI production. Revue de Métallurgie 2009;106:429433.

[15] Basu P. Gasification theory and modeling of gasifiers. In: Basu P, editor. Biomass Gasification and Pyrolysis: Practical Design and Theory. Burlington, MA: Academic Press; 2010.

[16] Spellman F. R. Forest-Based Biomass Energy: Concepts and Applications. CRC Press; 2011.

[17] GoBiGas; 2012. gobigas.goteborgenergi.se/En/The_plant. Accessed 2012-10-29 
[18] Ekerot S. Iron and steel production - Iron ore-based process metallurgy. (Järn- och stålframställning Malmbaserad processmetallurgi). Jernkontorets utbildningspaket del 2. Stockholm: Jernkontoret; 2000.

Available at: www.jernkontoret.se/ladda_hem_och_bestall/publikationer/stal_och_stalindustri/index.php (in Swedish)

[19] Widmark H. Iron and steel production - Scrap-based process metallurgy (Järn- och stålframställning Skrotbaseradbaserad processmetallurgi). Jernkontorets utbildningspaket del 3). Stockholm: Jernkontoret; 2000. Available at:

www.jernkontoret.se/ladda_hem_och_bestall/publikationer/stal_och_stalindustri/index.php (in Swedish)

[20] Lindqvist, Susanne. Sandvik AB. Personal communication. 2010-12-10.

[21] CEC - Chalmers Energy Centre (Chalmers EnergiCentrum). Biokombi Rya biomass gasification project final report (Biokombi Rya - Slutrapport från ingående delprojekt). CEC report No 2007:3, Gothenburg: Chalmers University of Technology; 2007. (in Swedish)

[22] Axelsson E, Harvey S. Scenarios for assessing profitability and carbon balances of energy investments in industry - Pathways to sustainable European energy systems. AGS Pathways report No 2010:EU1.

Gothenburg: AGS, The alliance for global sustainability; 2010.

[23] Axelsson E, Harvey S, Berntsson T. A tool for creating energy market scenarios for evaluation of investments in energy intensive industry. Energy 2009;34 (12):2069-2074.

[24] Heyne S, Harvey S. Assessment of energy and economic performance of second generation biofuel production processes using energy market scenarios. Applied Energy 2013;101:203-212.

[25] Fahlén E, Ahlgren EO. Assessment of integration of different biomass gasification alternatives in a district-heating system. Energy 2009;34:2184-2195.

[26] Wetterlund E, Söderström M. Biomass gasification in district heating systems - the effect of economic energy policies. Applied Energy 2010;87:2914-2922.

[27] IEA (International Energy Agency). World Energy Outlook 2011; 2011.

[28] CEPCl; 2011. Available at: www.che.com/pci/

[29] Remer DS, Chai LH. Design cost factors for scaling-up engineering equipment. Chemical Engineering and Processing 1990;86:77-82.

[30] Engström R, Gode J, Axelsson U. Guidance on the choice of methodology for calculating the impact on the Swedish environmental goals when changes in energy use are implemented (Vägledning till metodval vid beräkning av påverkan från förändrad energianvändning på de svenska miljömålen). Report No B1822, Stockholm: IVL Svenska Miljöinstitutet; 2009. (in Swedish)

[31] Fjärrsyn. Resource index of energy (Resursindex för energi). Report No 2011:7, Stockholm: Svensk Fjärrvärme; 2011. (in Swedish)

[32] Gode J, Martinsson F, Hagberg L, Öman A, Höglund J, Palm D. Milöfaktaboken 2011 - Estimated emission factors for fuels, electricity, heat and transport in Sweden (Miljöfaktaboken 2011 - Uppskattade emissionsfaktorer för bränslen, el, värme och transporter). Report No 1183, Stockholm: Värmeforsk; 2011. (in Swedish)

[33] Arnell J, Bolin L, Holmgren K, Staffas L, Adolfsson I, Lindblad M. Basis for increased use of excess heat (Förutsättningar för ökad nytta av restvärme). Report No 2012:14, Stockholm: IVL Svenska Miljöinstitutet; 2013. (in Swedish) 
[34] Hagberg L, Särnholm E, Gode J, Ekvall T, Rydberg T. LCA calculations on Swedish wood pellet production chains - according to the Renewable Energy Directive. IVL Report No B1873, Stockholm: IVL Swedish Environmental Research Institute Ltd; 2009.

[35] Gassner M, Maréchal F. Thermo-economic process model for thermochemical production of Synthetic Natural Gas (SNG) from lignocellulosic biomass. Biomass and Bioenergy 2009;33:2587-1604.

[36] Europe's energy portal; 2012. www.energy.eu/ Accesses 2012-10-29.

[37] FOEX Indexes LTD. PIX Pellet Nordic Index History Series; 2012.

[38] Lindqvist, Susanne. Sandvik AB. Personal communication 2013-03-15.

[39] Shulz TF, Barreto L, Kypreos S, Stucki S. Assessing wood-based synthetic natural gas technologies using the SWISS-MARKAL model. Energy 2007; 32:1948-1959.

[40] Hellsmark H, Jacobsson S. Realising the potential of gasified biomass in the European Union-Policy challenges in moving from demonstration plants to a larger scale diffusion. Energy Policy 2012:41;507-518.

[41] Ecofys. Financing Renewable Energy in the European Energy Market. European Commission 2011; Project number: PECPNL084659. Available at:

ec.europa.eu/energy/renewables/studies/doc/renewables/2011_financing_renewable.pdf

[42] Steubing B, Ballmer I, Gassner M, Gerber L, Pampuri L, Bischhof S, Thees O, Zah R. Identifying environmentally and economically optimal bioenergy plant sizes and locations: A spatial model of woodbased SNG value chains. Renewable Energy (2012), dx.doi.org/10.1016/j.renene.2012.08.018

[43] Steubing B, Zah R, Ludwig C. Life cycle assessment of SNG from wood for heating, electricity, and transportation. Biomass and Bioenergy 2011;35:2950-2960.

[44] Mathiesen B, Münster M, Fruergaard T. Uncertainties related to the identification of the marginal energy technology in consequential life cycle assessments. Journal of Cleaner Production 2009;17:13311338.

[45] Lundmark R, Mansikkasalo A. European trade of forest products in the presence of EU policy. Journal of Cleaner Production 2009;17:18-26.

[46] Cowiea AL, Gardner WD. Competition for the biomass resource: Greenhouse impacts and implications for renewable energy incentive schemes. Biomass and Bioenergy 2007;31:601-607.

[47] Steubing B, Zah R, Ludwig C. Heat, electricity, or transportation? The optimal use of residual and waste biomass in Europe from an environmental perspective. Environmental Science and Technology.

2012;46:164-171. 